\title{
Discovering Low Toxicity Ionic Liquids for Saccharomyces cerevisiae by Using the Agar Well Diffusion Test
}

\author{
Fatiha Missoun ${ }^{1,2, *}$, Antonia Pérez de los Ríos ${ }^{2}$, Víctor Ortiz-Martínez ${ }^{3}$, \\ María José Salar-García ${ }^{3}$, Jesús Hernández-Fernández ${ }^{2}$ \\ and Francisco José Hernández-Fernández ${ }^{2, *}$ \\ 1 Biotechnology Department, Faculty SNV, University of Mostaganem, Mostaganem 27000, Algeria \\ 2 Department of Chemical Engineering, Faculty of Chemistry, University of Murcia (UMU), P.O. Box 4021, \\ Campus de Espinardo, E-30100 Murcia, Spain; aprios@um.es (A.P.d.1.R.); \\ j.hernandezfernandez@um.es (J.H.-F.) \\ 3 Department of Chemical and Environmental Engineering, Technical University of Cartagena (UPCT), \\ Campus La Muralla, C/Doctor Fleming S/N, E-30202 Cartagena, Spain; victor.ortiz@upct.es (V.O.-M.); \\ mariajose.salar@upct.es (M.J.S.-G.) \\ * Correspondence: fatiha.missoun@yahoo.fr (F.M.); fjhernan@um.es (F.J.H.-F.)
}

Received: 16 August 2020; Accepted: 11 September 2020; Published: 16 September 2020

\begin{abstract}
Ionic liquids (ILs) are new solvents widely used in many technologies due to their unique and advantageous physicochemical properties. In biotechnological applications, ILs can be used along with microorganisms such as Saccharomyces cerevisiae. Due to the enormous number of ILs that can be synthesized through the combination of different anions and cations, it is necessary to have an easy and quick tool for the preliminary screening of their biocompatibility for being used in biotechnological applications. In this work, the agar well diffusion test was successfully applied as a rapid method to identify toxic/nontoxic ILs toward S. cerevisiae. Sixty-three ILs containing a diverse set of cations and anions were used. Through this methodology, nine fully biocompatible ILs toward S. cerevisiae were identified, including: $\left[\mathrm{Bmim}^{+}\right]\left[\mathrm{NO}_{3}{ }^{-}\right],\left[\mathrm{HOPmim}^{+}\right]\left[\mathrm{NO}_{3}{ }^{-}\right],\left[\mathrm{Bmim}^{+}\right]\left[\mathrm{NTf} 2^{-}\right]$, $\left[\mathrm{N}_{8,8,8,1^{+}}{ }^{+}\right]\left[\mathrm{NTf}_{2}^{-}\right],\left[\mathrm{S}_{2,2,2^{+}}\right]\left[\mathrm{NTf}_{2}{ }^{-}\right],\left[\mathrm{EMPyr}^{+}\right]\left[\mathrm{NTf}^{-}\right],\left[\mathrm{BMPi}^{+}\right]\left[\mathrm{NTf}^{-}\right],\left[\mathrm{Moxa}^{+}\right]\left[\mathrm{MeSO}_{4}{ }^{-}\right]$and $\left[\mathrm{Chol}^{+}\right]\left[\mathrm{H}_{2} \mathrm{PO}_{4}^{-}\right]$. The analysis of the results also provides preliminary rules to enable the design of biocompatible ILs with S. cerevisiae. In this context, the toxicity was mainly determined by the cation nature although some anions can also display a strong influence on the IL biocompatibility as the bistriflimide anion. Besides, it was observed that an increase in the alkyl chain length of cations, such as imidazolium or pyridinium, involves an increase in the IL toxicity.
\end{abstract}

Keywords: ionic liquids; toxicity; Saccharomyces cerevisiae; agar well diffusion test; biocompatibility

\section{Introduction}

In recent years, there has been an increasing biotechnological interest in Saccharomyces cerevisiae [1], which has been used to produce specific fuels, chemicals, and pharmaceutics, such as fatty acids and derivatives [2,3], terpenoids [4], ethanol [5], butanol and phenylethanol isomers [6] and pharmaceutical proteins [7].

At the same time, ionic liquids (ILs) are low-melting-point salts that have become increasingly attractive as green solvents for industrial applications. From an environmental point of view, their most important property is their practically zero vapor pressure. Furthermore, IL properties can be tailored for a specific application by accurately selecting the cation and the anion. Taking into account all these features, ILs are considered good candidates to be tested as extracting agents or solvents in 
biotechnological applications [8,9]. ILs have also been employed along with S. cerevisiae in several processes such as the improvement of the enzymatic hydrolysis of cellulose before fermentation with S. cerevisiae [10] and in biphasic systems for the synthesis of enantiomeric compounds such as 2-phenylethanol [11] or ethyl 2-hydroxy-4-phenylbutyrate catalyzed by this microorganism [12]. One of the most important limitations of ILs is their potential toxicity to certain microorganisms, which could challenge their application in these types of industrial processes $[13,14]$. For this reason, the number of research works in literature focusing on the study of the biocompatibility of ILs with different microorganisms has significantly increased in recent years [15-22]. Furthermore, due to the enormous number of ILs that can be synthesized by the combination of different anions and cations, it is necessary to develop easy and quick tools for the preliminary selection of biocompatible ILs. The agar well diffusion test, used to assess the toxicity in solid media, is simple, inexpensive, requires little preparation, no specialized equipment and uses small quantities of sample. The antimicrobial activity is assessed through the diameter of the inhibition zones obtained by the addition of the ILs (in a pure state or high concentration solutions) in wells punched in the agar plate precultured with the fresh microorganism. In any case, this methodology could be used as a first stage to identify the most promising ILs for use in a wide range of processes [20,23-25].

In this context, this work aims at investigating the potential toxicity and biocompatibility of 63 ILs containing different cation and anion structures with S. cerevisiae, the most widely used microorganism for ethanol fermentation. Imidazolium, pyridinium, pyrrolidinium, piperidinium, morpholinium, oxazolinium, phosphonium, ammonium and sulfonium cations combined with different anions have been analyzed in solid media by using the well diffusion test. The results obtained are in-depth discussed and related to the structural characteristic of the ILs, which allows the identification of key factors for designing biocompatible IL toward S. cerevisiae.

\section{Materials and Methods}

\subsection{Ionic Liquids and Chemicals}

The 63 ILs investigated in the current work are grouped according to the type of cation present in their structure. Tables 1-6 include the name of each IL analyzed along with its structure and water solubility. The biocompatible water-insoluble ILs might be used as extraction agents of organic compounds from aqueous media while nontoxic water-soluble ILs could be employed as a reaction media in biocatalytic synthesis by using $S$. cerevisiae. The tables also include the nomenclature used for each IL (abbreviation name), as well as, the radius of inhibition (RI), caused on S. cerevisiae. All ILs were supplied by IoLiTec (Ionic Liquids Technologies, Germany) and were of the highest purity available.

\subsection{Culture of S. cerevisiae}

The yeast $S$. cerevisiae was selected as a microorganism to evaluate the potential toxicity of different ILs. A suspension of $1 \mathrm{~g} \mathrm{~L}^{-1}$ of the yeast was prepared in physiological water $\left(9 \mathrm{~g} \mathrm{~L}^{-1}\right)$ and then, $200 \mu \mathrm{L}$ of this solution was transferred to yeast extract-peptone-dextrose (YPD) agar plates with the following composition in $\mathrm{g} \mathrm{L}^{-1} 20_{\mathrm{D} \text {-glucose }} / 20_{\text {peptone }} / 10_{\text {yeast extract }} / 20_{\text {agar }}$ and incubated for $48 \mathrm{~h}$. The inoculum was prepared by adding a single colony of the yeast to a flask containing $100 \mathrm{~mL}$ of YPD liquid medium prepared with $20_{\mathrm{D} \text {-glucose }} / 20_{\text {peptone }} / 10_{\text {yeast extract }}\left(\mathrm{g} \mathrm{L}^{-1}\right)$. The flask was incubated in an orbital shaker at $170 \mathrm{rpm}$ and $30^{\circ} \mathrm{C}$ for $24 \mathrm{~h}$. Both solid and liquid YDP media were autoclaved at $121^{\circ} \mathrm{C}$ for $20 \mathrm{~min}$. All the reagents were purchased from Sigma Aldrich and were of the highest purity available.

\subsection{Toxicity Analysis: Agar Well Diffusion Test}

The toxicity of the different ILs to $S$. cerevisiae was studied by using the well agar diffusion test $[26,27]$. This method consists of making wells of $6 \mathrm{~mm}$ of diameter by punching an agar plate with a glass tube under sterilized conditions. Aliquots of $50 \mu \mathrm{L}$ of each IL were placed on the wells, using physiological water for the control wells without IL $[25,28,29]$. The agar plates were incubated 
at $30{ }^{\circ} \mathrm{C}$ for $48 \mathrm{~h}$ and then, the radius of the inhibition zone around the wells was determined (see Figure 1). Each IL was tested in triplicate and the size of the inhibition zone was measured by using a Vernier scale. The results showed are the average of the triplicates and the standard deviations.

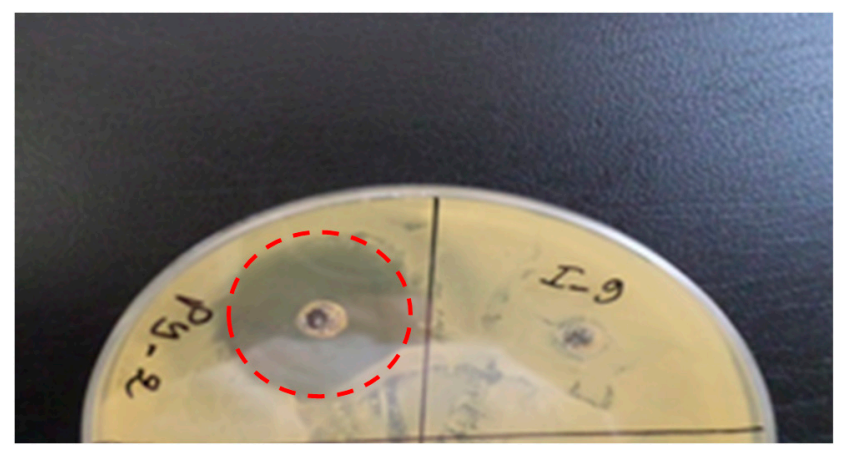

Figure 1. Inhibition zone in well agar diffusion test for the 1-butyl-3-methylpyridinium tetrafluoroborate $\left[\mathrm{BMpy}^{+}\right]\left[\mathrm{BF}_{4}^{-}\right]$(very toxic) on the left side of the agar plate, and 1-butyl-3-methylimidazolium bis (trifluoromethylsulphonyl) imide $\left[\mathrm{Bmim}^{+}\right]\left[\mathrm{NTf}^{-}\right]$(biocompatible) on the right side of the agar plate.

\section{Results and Discussion}

The biocompatibility of 63 ILs toward S. cerevisiae was assessed by using the agar well diffusion test previously described. The names of these compounds and the results obtained are shown in Tables 1-6. The importance of evaluating the compatibility of ILs with S. cerevisiae lies in the development of new biotechnological processes that combine ILs and S. cerevisiae as it has been recently reported by de los Ríos et al. [19]. In this previous work, they evaluated the toxicity of nine water-insoluble ILs toward S. cerevisiae using the agar diffusion test (in pure form and 3\%v/v IL solution), specific growth rates $\left(\mu, h^{-1}\right)$ in liquid media at 3\% $(v / v)$ IL and the final dry-weight concentration of yeast at $48 \mathrm{~h} \mathrm{[19].}$ The toxicity results found by the authors with the agar diffusion test were similar to those achieved in the rest of the toxicity assays evaluated (growth in liquid media and final dry weight concentration), which confirms the suitability of the well diffusion test as a simple method to estimate the toxicity of ILs toward S. cerevisiae [19]. In this context, the growth rate S. cerevisiae in the presence of ILs which exhibited zero inhibition radius (agar diffusion test, pure ILs) was similar to the growth rate of the control without IL. These preliminary results allow us to classify the toxicity of ILs as 'very toxic' when the inhibition radius is higher than $1 \mathrm{~cm}$, as 'toxic' when de inhibition radius is between 1 and $0.5 \mathrm{~cm}$, as 'low toxic' when it is between 0.5 and $0.0 \mathrm{~cm}$ and as 'biocompatible' when the inhibition radius is equal to zero. The IL $\left[\mathrm{Omim}^{+}\right]\left[\mathrm{dca}^{-}\right]$is very toxic and, on the contrary, $\left[\mathrm{HOPmim}{ }^{+}\right]\left[\mathrm{NO}_{3}{ }^{-}\right]$and $\left[\mathrm{Bmim}^{+}\right]$ $\left[\mathrm{NTf}^{-}\right.$] can be considered biocompatible with S. cerevisiae (see Table 1). On the other hand, it was found that water solubility was not directly related to the toxicity of the ILs toward S. cerevisiae as can be observed in Table 1. For instance, some ILs that are water-insoluble are very toxic (e.g., $\left[\mathrm{P}_{6,6,6,14}{ }^{+}\right]$ $\left[\mathrm{C}_{9} \mathrm{COO}^{-}\right]$, see Table 2) while other water-soluble ILs are low toxic or even biocompatible with the yeast (e.g., $\left[\mathrm{Omim}^{+}\right]\left[\mathrm{dca}^{-}\right]$, see Table 1$)$. This implies that it is necessary to analyze the relationship between toxicity and IL structure. In the following sections, we systematically analyze the qualitative relationship between IL structure and toxicity. 
Table 1. Biocompatibility data of imidazolium-based ionic liquids toward S. cerevisiae using agar well diffusion test.

\begin{tabular}{|c|c|c|c|c|c|c|}
\hline Full Name & Abbreviation & Structure & Water Miscibility & State $25^{\circ} \mathrm{C}$ & Ref. & $\begin{array}{l}\text { Radius of Inhibition (RI) } \\
(\mathrm{cm})\end{array}$ \\
\hline 1-(2-hydroxypropyl)-methylimidazolium chloride & {$\left[\mathrm{HOPmim}^{+}\right]\left[\mathrm{Cl}^{-}\right]$} & & Soluble & Liquid & [19] & $0.1 \pm 0.0$ \\
\hline 1-butyl-3-methylimidazolium chloride & {$\left[\mathrm{Bmim}^{+}\right]\left[\mathrm{Cl}^{-}\right]$} & & Soluble & Solid & [29] & $0.6 \pm 0.1$ \\
\hline 1-hexyl-3-methylimidazolium chloride & {$\left[\mathrm{Hmim}^{+}\right]\left[\mathrm{Cl}^{-}\right]$} & & Soluble & Liquid & [19] & $1.3 \pm 0.5$ \\
\hline 1-butyl-3 methylimidazolium tetrafluoroborate & {$\left[\mathrm{Bmim}^{+}\right]\left[\mathrm{BF}_{4}^{-}\right]$} & & Soluble & Liquid & [30] & $0.7 \pm 0.2$ \\
\hline 1-methyl-3-octylimidazolium tetrafluoroborate & {$\left[\mathrm{Omim}^{+}\right]\left[\mathrm{BF}_{4}^{-}\right]$} & & Insoluble (decomposes in water) & Liquid & {$[31,32]$} & $1.3 \pm 0.4$ \\
\hline $\begin{array}{l}\text { 1-butyl-2,3-dimethylimidazolium } \\
\text { tetrafluoroborate }\end{array}$ & {$\left[\mathrm{BDImim}^{+}\right]\left[\mathrm{BF}_{4}^{-}\right]$} & & Soluble & Liquid & [19] & $0.30 \pm 0.15$ \\
\hline $\begin{array}{l}\text { 1-methoxymethyl-3-methylimidazolium } \\
\text { tetrafluoroborate }\end{array}$ & {$\left[\mathrm{MOMmim}^{+}\right]\left[\mathrm{BF}_{4}^{-}\right]$} & & Soluble & Liquid & [19] & $0.2 \pm 0.0$ \\
\hline $\begin{array}{l}\text { 1-methoxyethyl-3-methylimidazolium } \\
\text { tetrafluoroborate }\end{array}$ & {$\left[\mathrm{MOEmim}^{+}\right]\left[\mathrm{BF}_{4}^{-}\right]$} & & Insoluble & Liquid & [19] & $0.7 \pm 0.1$ \\
\hline $\begin{array}{l}\text { 1-butyl-3-methylimidazolium } \\
\text { hexafluorophosphate }\end{array}$ & {$\left[\mathrm{Bmim}^{+}\right]\left[\mathrm{PF}_{6}^{-}\right]$} & & Insoluble & Liquid & [33] & $0.4 \pm 0.1$ \\
\hline $\begin{array}{l}\text { 1-methyl-3-octylimidazolium } \\
\text { hexafluorophosphate }\end{array}$ & {$\left[\mathrm{Omim}^{+}\right]\left[\mathrm{PF}_{6}^{-}\right]$} & & Insoluble(decomposition in water) & Liquid & {$[31,32,34]$} & $0.5 \pm 0.1$ \\
\hline $\begin{array}{l}\text { 1-methoxymethyl-3-methylimidazolium } \\
\text { hexafluorophosphate }\end{array}$ & {$\left[\mathrm{MOMmim}^{+}\right]\left[\mathrm{PF}_{6}^{-}\right]$} & & Soluble & Solid & [31] & $2.0 \pm 0.5$ \\
\hline 1-butyl-3-methylimidazolium nitrate & {$\left[\mathrm{Bmim}^{+}\right]\left[\mathrm{NO}_{3}{ }^{-}\right]$} & & Soluble & Liquid & [19] & 0.0 \\
\hline
\end{tabular}


Table 1. Cont.

\begin{tabular}{|c|c|c|c|c|c|c|}
\hline Full Name & Abbreviation & Structure & Water Miscibility & State $25^{\circ} \mathrm{C}$ & Ref. & $\begin{array}{l}\text { Radius of Inhibition (RI) } \\
(\mathrm{cm})\end{array}$ \\
\hline $\begin{array}{l}\text { 1-(2-hydroxypropyl)-3-methylimidazolium } \\
\text { nitrate }\end{array}$ & {$\left[\mathrm{HOPmim}^{+}\right]\left[\mathrm{NO}_{3}{ }^{-}\right]$} & & Soluble & Liquid & [19] & 0.0 \\
\hline 1-butyl-3-methylimidazolium acetate & {$\left[\mathrm{Bmim}^{+}\right]\left[\mathrm{CH}_{3} \mathrm{COO}^{-}\right]$} & & Soluble & Liquid & [19] & $1.0 \pm 0.2$ \\
\hline 1-butyl-3-methylimidazolium glycolate & {$\left[\mathrm{Bmim}^{+}\right]\left[\mathrm{CH}_{2} \mathrm{OHCOO}^{-}\right]$} & & Soluble & Liquid & [19] & $0.3 \pm 0.1$ \\
\hline 1-butyl-3-methylimidazolium methylcarbonate & {$\left[\mathrm{Bmim}^{+}\right]\left[\mathrm{MeCOO}_{2}^{-}\right]$} & & Soluble & Liquid & [31] & $1.0 \pm 0.3$ \\
\hline
\end{tabular}

Table 2. Biocompatibility data of phosphonium-based ionic liquids toward S. cerevisiae using agar well diffusion test.

\begin{tabular}{|c|c|c|c|c|c|c|}
\hline Full Name & Abbreviation & Structure & Water Miscibility & State at $25^{\circ} \mathrm{C}$ & Ref. & $\begin{array}{c}\text { Radius of Inhibition (RI) } \\
(\mathrm{cm})\end{array}$ \\
\hline 1-butyl-3-methylimidazolium thiocyanate & {$\left[\mathrm{Bmim}^{+}\right]\left[\mathrm{SCN}^{-}\right]$} & & Insoluble & Liquid & [35] & $0.8 \pm 0.3$ \\
\hline $\begin{array}{l}\text { 1-(2-hydroxypropyl) -methylimidazolium } \\
\text { dicyanamide }\end{array}$ & {$\left[\mathrm{HOPmim}^{+}\right]\left[\mathrm{dca}^{-}\right]$} & & Soluble & Liquid & [19] & $0.05 \pm 0.00$ \\
\hline 1-butyl-3-methylimidazolium dicyanamide & {$\left[\mathrm{Bmim}^{+}\right]\left[\mathrm{dca}^{-}\right]$} & & Soluble & Liquid & [36] & $0.6 \pm 0.2$ \\
\hline 1-hexyl-3-methylimidazolium dicyanamide & {$\left[\mathrm{Hmim}^{+}\right]\left[\mathrm{dca}^{-}\right]$} & & Soluble & Liquid & [19] & $0.5 \pm 0.2$ \\
\hline 1-methyl-3-octylimidazolium dicyanamide & {$\left[\mathrm{Omim}^{+}\right]\left[\mathrm{dca}^{-}\right]$} & & Soluble & Liquid & [36] & $2.0 \pm 0.2$ \\
\hline $\begin{array}{l}\text { 1-methoxyethyl-3-methylimidazolium } \\
\text { dicyanamide }\end{array}$ & {$\left[\mathrm{MOEmim}^{+}\right]\left[\mathrm{dca}^{-}\right]$} & & Soluble & Liquid & [31] & $1.0 \pm 0.2$ \\
\hline 1-butyl-3-methylimidazolium hydrogen sulfate & {$\left[\mathrm{Bmim}^{+}\right]\left[\mathrm{HSO}_{4}^{-}\right]$} & & Soluble & Liquid & [31] & $0.5 \pm 0.1$ \\
\hline
\end{tabular}


Table 2. Cont

\begin{tabular}{|c|c|c|c|c|c|c|}
\hline Full Name & Abbreviation & Structure & Water Miscibility & State at $25^{\circ} \mathrm{C}$ & Ref. & $\begin{array}{c}\text { Radius of Inhibition (RI) } \\
(\mathrm{cm})\end{array}$ \\
\hline 1,2,3-trimethylimidazolium methylsulfate & {$\left[\left(\mathrm{CH}_{3}\right)_{3} \mathrm{IM}^{+}\right]\left[\mathrm{CH}_{3} \mathrm{SO}_{4}^{-}\right]$} & & Partly soluble & Solid & [37] & $0.3 \pm 0.1$ \\
\hline $\begin{array}{l}\text { 1-(ethoxyethyl)-3-methylimidazolium } \\
\text { trifluoromethanesulfonate }\end{array}$ & {$\left[\mathrm{EOEmim}^{+}\right]\left[\mathrm{CF}_{3} \mathrm{SO}_{3}^{-}\right]$} & & Soluble & Liquid & {$[38]$} & $0.5 \pm 0.1$ \\
\hline $\begin{array}{l}\text { 1-butyl-3 methylimidazolium } \\
\text { 1,1,2,2-tetrafluoroethanesulfonate }\end{array}$ & {$\left[\mathrm{Bmim}^{+}\right]\left[\mathrm{TFES}^{-}\right]$} & & Soluble & Liquid & [39] & $0.9 \pm 0.2$ \\
\hline $\begin{array}{l}\text { 1-ethyl-3-methylimidazolium bis } \\
\text { (trifluoromethylsulfonyl) imide }\end{array}$ & {$\left[\mathrm{Emim}^{+}\right]\left[\mathrm{NTf2}^{-}\right]$} & & Insoluble & Liquid & [40] & $0.10 \pm 0.09$ \\
\hline $\begin{array}{l}\text { 1-butyl-3 methylimidazolium bis } \\
\text { (trifluoromethylsulfonyl) imide }\end{array}$ & {$\left[\mathrm{Bmim}^{+}\right]\left[\mathrm{NTf}^{-}\right]$} & & Insoluble & Liquid & [36] & 0.0 \\
\hline $\begin{array}{l}\text { 1-methyl-3-octylimidazolium bis } \\
\text { (trifluoromethylsulfonyl) imide }\end{array}$ & {$\left[\mathrm{Omim}^{+}\right]\left[\mathrm{NTf}_{2}^{-}\right]$} & 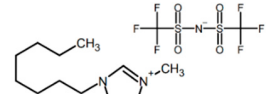 & Insoluble & Liquid & [36] & $0.3 \pm 0.1$ \\
\hline Tetradecyl (trihexyl) phosphonium chloride & {$\left[\mathrm{P}_{6,6,6,6,14}{ }^{+}\right]\left[\mathrm{Cl}^{-}\right]$} & & Insoluble & Liquid & {$[31,41]$} & $0.20 \pm 0.05$ \\
\hline Tetradecyl (trihexyl) phosphonium bromide & {$\left[\mathrm{P}_{6,6,6,6,14}{ }^{+}\right]\left[\mathrm{Br}^{-}\right]$} & $\begin{array}{c}\mathrm{H}_{13} \mathrm{C}_{6}-\mathrm{P}^{-}+\mathrm{P}^{+}+\mathrm{P}_{6} \mathrm{H}_{13} \\
\mathrm{C}_{14} \mathrm{C}_{29}\end{array}$ & Insoluble & Liquid & {$[31,42]$} & $0.90 \pm 0.25$ \\
\hline Tetraoctylphosphonium bromide & {$\left[\mathrm{P}_{8,8,8,8}{ }^{+}\right]\left[\mathrm{Br}^{-}\right]$} & $\begin{array}{c}\mathrm{CH}_{2}\left(\mathrm{CH}_{2 / 6} \mathrm{CH}_{3}\right. \\
\mathrm{H}_{3} \mathrm{CH}_{2} \mathrm{H}_{2} \mathrm{Cr}_{6} \mathrm{H}_{2} \mathrm{C}-\mathrm{P}^{-}-\mathrm{CH}_{2}\left(\mathrm{CH}_{26} \mathrm{CH}_{3}\right. \\
\mathrm{CH}_{2}\left(\mathrm{CH}_{2} / 6 \mathrm{CH}_{3}\right.\end{array}$ & Insoluble & Solid & {$[31,43]$} & $0.5 \pm 0.1$ \\
\hline $\begin{array}{l}\text { Tetradecyl (trihexyl) phosphonium } \\
\text { tetrafluoroborate }\end{array}$ & {$\left[\mathrm{P}_{6,6,6,6,14^{+}}\right]\left[\mathrm{BF}_{4}^{-}\right]$} & $\begin{array}{cc}\mathrm{C}_{6} \mathrm{H}_{13} & \mathrm{f} \\
\mathrm{H}_{13} \mathrm{C}_{6}-\mathrm{P}_{13}-\mathrm{C}_{6} \mathrm{H}_{13} & \mathrm{~F}-\mathrm{I}-\mathrm{F} \\
\mathrm{C}_{14} \mathrm{C}_{29} & \mathrm{~F}\end{array}$ & Insoluble & Liquid & {$[31,44]$} & $0.60 \pm 0.15$ \\
\hline Tetrabutylphosphonium dibutyl phosphate & {$\left[\mathrm{P}_{4,4,4,4}{ }^{+}\right]\left[\mathrm{Bu}_{2} \mathrm{Phos}^{-}\right]$} & $\begin{array}{cc}\mathrm{C}_{4} \mathrm{H}_{9} & \rho^{-} \\
\mathrm{H}_{9} \mathrm{C}_{4}-P^{+}-\mathrm{P}_{4} \mathrm{H}_{9} & \mathrm{O}=\mathrm{P}-\mathrm{OC}_{4} \mathrm{H}_{9} \\
\mathrm{C}_{4} \mathrm{H}_{9} & \mathrm{OC}_{4} \mathrm{H}_{9}\end{array}$ & Soluble & Solid & {$[31,45]$} & $0.5 \pm 0.1$ \\
\hline $\begin{array}{l}\text { Trihexyl (tetradecyl) phosphonium bis } \\
\text { 2,4,4-(trimethylpentyl) phosphinate }\end{array}$ & {$\left[\mathrm{P}_{6,6,6,14}{ }^{+}\right]\left[\mathrm{TMPPhos}^{-}\right]$} & 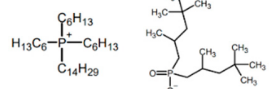 & Insoluble & Liquid & {$[31,46]$} & $0.5 \pm 0.1$ \\
\hline
\end{tabular}


Table 2. Cont.

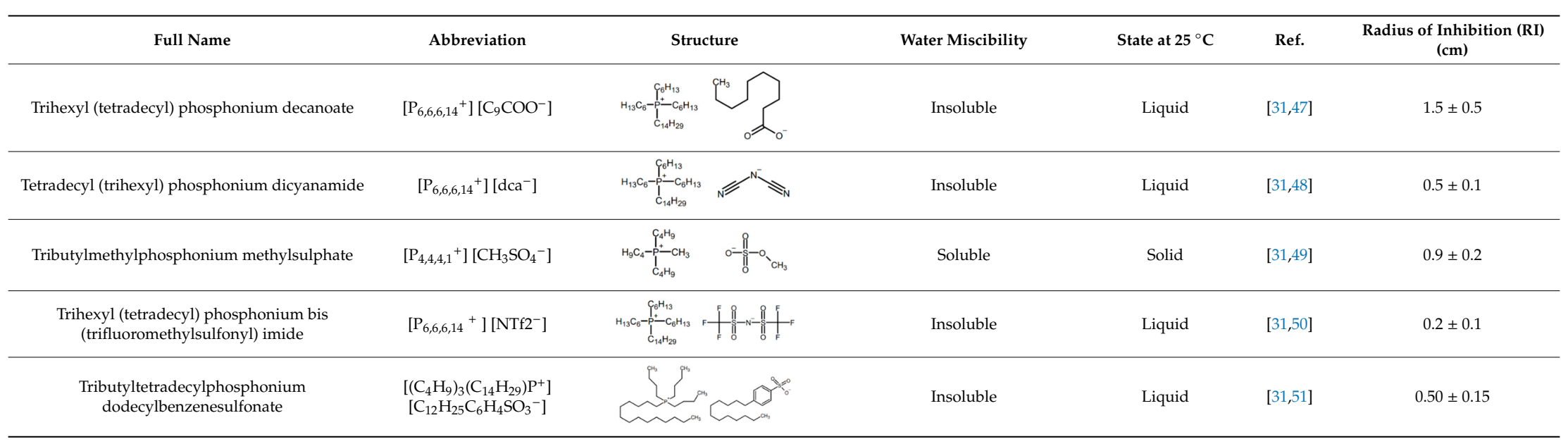

Table 3. Biocompatibility data of pyrrolidinium-based ionic liquids toward S. cerevisiae using agar well diffusion test.

\begin{tabular}{|c|c|c|c|c|c|c|}
\hline Full Name & Abbreviation Name & Structure & Water Miscibility & State $25^{\circ} \mathrm{C}$ & Ref. & $\begin{array}{l}\text { Radius of Inhibition (RI) } \\
(\mathrm{cm}))\end{array}$ \\
\hline $\begin{array}{l}\text { 1-butyl-1-methyl pyrrolidinium } \\
\text { hexafluorophosphate }\end{array}$ & {$\left[\mathrm{BMPyr}^{+}\right]\left[\mathrm{PF}_{6}^{-}\right]$} & & Insoluble & Solid & {$[52,53]$} & $0.7 \pm 0.1$ \\
\hline 1-butyl-1-methyl pyrrolidinium dicyanamide & {$\left[\mathrm{BMPyr}^{+}\right]\left[\mathrm{dca}^{-}\right]$} & & Soluble & Liquid & {$[54,55]$} & $0.4 \pm 0.1$ \\
\hline 1-butyl-1-methyl pyrrolidinium triflate & {$\left[\mathrm{BMPyr}^{+}\right]\left[\mathrm{TFO}^{-}\right]$} & & Soluble & Liquid & {$[56,57]$} & $0.20 \pm 0.05$ \\
\hline $\begin{array}{l}\text { 1-ethyl-1-methyl pyrrolidinium } \\
\text { bis[(trifluoromethyl) sulfonyl]imide }\end{array}$ & {$\left[\mathrm{EMPyr}^{+}\right]\left[\mathrm{NTf2}^{-}\right]$} & & Insoluble & Solid & {$[31,58]$} & 0.0 \\
\hline $\begin{array}{l}\text { 1-butyl-1-methyl pyrrolidinium bis } \\
\text { (trifluoromethylsulfonyl) imide }\end{array}$ & {$\left[\mathrm{BMPyr}^{+}\right]\left[\mathrm{NTf2}^{-}\right]$} & & Insoluble & Liquid & {$[57,59]$} & $1.10 \pm 0.35$ \\
\hline
\end{tabular}


Table 4. Biocompatibility data of pyridinium-based ionic liquids toward S. cerevisiae using agar well diffusion test.

\begin{tabular}{|c|c|c|c|c|c|c|}
\hline Full Name & Abbreviation Name & Structure & Water Miscibility & State $25^{\circ} \mathrm{C}$ & Ref. & $\begin{array}{c}\text { Radius of Inhibition (RI) } \\
(\mathrm{cm})\end{array}$ \\
\hline $\begin{array}{l}\text { 1-butyl-3-methylpyridinium } \\
\text { tetrafluoroborate }\end{array}$ & {$\left[\mathrm{BMPy}^{+}\right]\left[\mathrm{BF}_{4}^{-}\right]$} & & Soluble & Liquid & {$[31,60]$} & $1.4 \pm 0.2$ \\
\hline 1-butyl-3-methylpyridinium dicyanamide & {$\left[\mathrm{BMPy}^{+}\right]\left[\mathrm{dca}^{-}\right]$} & & Soluble & Liquid & {$[31,61,62]$} & $1.1 \pm 0.3$ \\
\hline $\begin{array}{l}\text { 1-methyl-3-octylpyridinium } \\
\text { dicyanamide }\end{array}$ & {$\left[\mathrm{MOPy}^{+}\right]\left[\mathrm{dca}^{-}\right]$} & & Insoluble & Liquid & [31] & $0.5 \pm 0.2$ \\
\hline $\begin{array}{l}\text { 1,4-dimethyl pyridinium } \\
\text { Methylsulfate }\end{array}$ & {$\left[\mathrm{MMPy}^{+}\right]\left[\mathrm{Me} \mathrm{SO}_{4}^{-}\right]$} & & Soluble & Solid & [31] & $0.4 \pm 0.1$ \\
\hline $\begin{array}{l}\text { 1-ethylpyridinium } \\
\text { ethyl sulfate }\end{array}$ & {$\left[\mathrm{EPy}^{+}\right]\left[\mathrm{EtSO}_{4}^{-}\right]$} & & Soluble & Liquid & {$[31,63]$} & $0.5 \pm 0.2$ \\
\hline $\begin{array}{l}\text { 1-ethylpyridinium } \\
\text { bis(trifluoromethylsulfonyl)imide }\end{array}$ & {$\left[\mathrm{EPy}^{+}\right]\left[\mathrm{NTf2}^{-}\right]$} & & Insoluble & Liquid & {$[31,63,64]$} & $0.5 \pm 0.15$ \\
\hline
\end{tabular}

Table 5. Biocompatibility data of ammonium-based ionic liquids toward S. cerevisiae using agar well diffusion test.

\begin{tabular}{ccccc}
\hline Full Name & Abbreviation Name & Water Miscibility & State at 25 ${ }^{\circ} \mathrm{C}$ & Ref. \\
Methyltrioctylammonium chloride & {$\left[\mathrm{N}_{\left.8,8,8,1^{+}\right]\left[\mathrm{Cl}^{-}\right]}\right.$} & Radius of Inhibition (RI) \\
(cm)
\end{tabular}


Table 5. Cont.

\begin{tabular}{|c|c|c|c|c|c|c|}
\hline Full Name & Abbreviation Name & Structure & Water Miscibility & State at $25^{\circ} \mathrm{C}$ & Ref. & $\begin{array}{l}\text { Radius of Inhibition }(R I) \\
(\mathrm{cm})\end{array}$ \\
\hline $\begin{array}{l}\text { Methyltrioctylammoniumbis } \\
\text { (trifluoromethylsulfonyl) imide }\end{array}$ & {$\left[\mathrm{N}_{8,8,8,1^{+}}\right]\left[\mathrm{NTf2}^{-}\right]$} & & Insoluble & liquid & {$[68]$} & 0.0 \\
\hline $\begin{array}{l}\text { Cocosalkylpentaethoximethylammonium } \\
\text { methylsulfate }\end{array}$ & {$\left[\mathrm{C} 1 \mathrm{EG}^{+}\right]\left[\mathrm{MeSO}_{4}^{-}\right]$} & & Soluble & Liquid & {$[31,69]$} & $1.0 \pm 0.3$ \\
\hline $\begin{array}{l}\text { Tallowsalkylpentaethoximethylammonium } \\
\text { methylsulfate }\end{array}$ & {$\left[\mathrm{T}^{2} \mathrm{EG}^{+}\right]\left[\mathrm{MeSO}_{4}^{-}\right]$} & & Insoluble & Liquid & {$[31,70]$} & $0.7 \pm 0.2$ \\
\hline $\mathrm{TEGO}^{\circledR}$-IL-P9 & {$\left[221 \mathrm{PG}^{+}\right]\left[\mathrm{Cl}^{-}\right]$} & & Soluble & Liquid & {$[31,71]$} & $0.20 \pm 0.05$ \\
\hline Choline bis (trifluoromethylsulfonyl) imide & {$\left[\mathrm{Chol}^{+}\right]\left[\mathrm{NTf2}^{-}\right]$} & & Insoluble & Liquid & {$[31,72,73]$} & $0.1 \pm 0.0$ \\
\hline
\end{tabular}

Table 6. Biocompatibility data of piperidinium-, morpholinium-, oxazolinium- and sulfonium-based ionic liquids toward S.cerevisiae using agar well diffusion test.

\begin{tabular}{|c|c|c|c|c|c|c|}
\hline Full Name & Abbreviation Name & Structure & Water Miscibility & State at $25^{\circ} \mathrm{C}$ & Ref. & $\begin{array}{c}\text { Radius of Inhibition (RI) } \\
(\mathrm{cm})\end{array}$ \\
\hline $\begin{array}{l}\text { 1-butyl-1-methylpiperidiniumbis } \\
\text { (trifluoromethylsulfonyl) imide }\end{array}$ & {$\left[\mathrm{BMPi}^{+}\right]\left[\mathrm{NTf}^{-}\right]$} & & Insoluble & Liquid & {$[31,74]$} & 0.0 \\
\hline Ethyl methyl morpholinium dicyanamide & {$\left[\mathrm{EMMOR}^{+}\right]\left[\mathrm{dca}^{-}\right]$} & & Soluble & Liquid & {$[19,75]$} & $0.6 \pm 0.3$ \\
\hline Methyloxazolinium methylsulfate & {$\left[\mathrm{Moxa}^{+}\right]\left[\mathrm{MeSO}_{4}^{-}\right]$} & & Soluble & Liquid & {$[19,31]$} & 0.0 \\
\hline $\begin{array}{l}\text { Triethylsulfonium bis (trifluoromethylsulfonyl) } \\
\text { imide }\end{array}$ & {$\left[\mathrm{S}_{2,2,2^{+}}{ }^{+}\left[\mathrm{NTf2} 2^{-}\right]\right.$} & & Insoluble & Liquid & [76] & 0.0 \\
\hline
\end{tabular}




\subsection{Influence of the Alkyl Substituent of the Cation of Ionic Liquid on the Toxicity toward S. cerevisiae}

According to the results obtained, an increase of the alkyl chain length in the IL cation (considering the same anion) involves an increase in the toxicity of the ILs to $S$. cerevisiae. This behaviour is found for the imidazolium cation (see Table 1) from $\left[\mathrm{Bmim}^{+}\right]\left[\mathrm{Cl}^{-}\right]$to $\left[\mathrm{Hmim}^{+}\right]\left[\mathrm{Cl}^{-}\right]$(in which the ILs range from toxic to very toxic), from $\left[\mathrm{Bmim}^{+}\right]\left[\mathrm{BF}_{4}^{-}\right]$to $\left[\mathrm{Hmim}^{+}\right]\left[\mathrm{BF}_{4}^{-}\right]$, from $\left[\mathrm{MOMmim}^{+}\right]\left[\mathrm{BF}_{4}^{-}\right]$to $\left[\mathrm{MOEmim}{ }^{+}\right]$ $\left[\mathrm{BF}_{4}{ }^{-}\right]$, from $\left[\mathrm{Bmim}^{+}\right]\left[\mathrm{dca}^{-}\right],\left[\mathrm{Hmim}^{+}\right]\left[\mathrm{dca}^{-}\right]$to $\left[\mathrm{Omim}^{+}\right]\left[\mathrm{dca}^{-}\right]$and from $\left[\mathrm{Bmim}^{+}\right]\left[\mathrm{PF}_{6}{ }^{-}\right]$to $\left[\mathrm{Omim}^{+}\right]$ $\left[\mathrm{PF}_{6}{ }^{-}\right]$. This behavior was also observed for the pyrrolidinium cation (see Table 3) from [Empyr $\left.{ }^{+}\right]$ $\left[\mathrm{NTf}^{-}\right]$to $\left[\mathrm{Bmpyr}^{+}\right]\left[\mathrm{NTf2}^{-}\right](0$ and $1.1 \mathrm{~cm}$ of inhibition radius, respectively). Sendovski et al. [11] studied the toxicity of nine immiscible ILs toward S. cerevisiae, used in biphasic systems in the synthesis of 2-phenylethanol catalyzed by this yeast. To this aim, S. cerevisiae was grown in the presence of the selected ILs. The results found are in line with those obtained in the present work since the longer the alkyl side chain on the imidazolium ring, the lower biocompatibility of the ILs. In other microorganisms, it was also found that the toxicity was directly related to the chain length of the alkyl substituent on the cation [19,77-80]. The influence of an increasing chain length of the imidazolium cation moiety on the cytotoxicity in marine bacteria and two types of mammalian cell cultures were also evident in HeLa cells [81,82]. This effect is currently known as the 'side-chain effect' [83]. For highly lipophilic cations, cytotoxicity does not significantly increase with lipophilicity anymore. It is well known that lipophilicity relationships with biological activity are only linear over a restricted range [84]. The 'side-chain effect', in which carbon atoms are added, involves a high hydrophobic character in ILs. It would increase the possibility of their interaction with phospholipid bilayers of the cell membranes and the hydrophobic domains of the membrane proteins, leading to the disruption of the membrane physiological functions and, consequently, to cell death $[81,82,85,86]$. On the contrary, as can be observed in Table 1, the inclusion of an oxygen atom in the alkyl substituent of the imidazolium ring can significantly decrease the toxicity of imidazolium-based ILs. It has been observed that [HOPmim $\left.{ }^{+}\right]$ $\left[\mathrm{Cl}^{-}\right](R I=0.1 \mathrm{~cm})$ displayed much lower toxic effects than $\left[\mathrm{Bmim}^{+}\right]\left[\mathrm{Cl}^{-}\right](R I=0.6 \mathrm{~cm})$, so the substitution of the methyl by a hydroxy group converts a toxic IL into a slightly toxic IL. This behavior is in agreement with the work of Álvarez-Guerra and Irabien [87], who reported that the presence of oxygenated groups in the structure of cations can lead to a decrease in the ecotoxicity of the IL. In line with these results, Tether et al. [88] reported the decrease in the ionic liquid toxicity toward Escherichia coli and Staphylococcus epidermidis through the side chain oxygenation by using the agar diffusion test. In this context, the presence of the oxygen makes the IL more hydrophilic, and therefore, less toxic. It is also important to remark the high toxicity observed for $\left[\mathrm{Bmim}^{+}\right]\left[\mathrm{BF}_{4}^{-}\right]$compared to [BDImim $\left.{ }^{+}\right]$ $\left[\mathrm{BF}_{4}^{-}\right]$. The inclusion of the methyl substituent in the $\mathrm{R} 2$ position of the imidazolium ring could reduce the acidic proton in 2 , so lowering the toxicity of the IL. This effect was also recently observed for Shewanella [89].

\subsection{Effect of the Ionic Liquid Cation on Toxicity toward S. cerevisiae}

In order to study the effect of the cation structure, ILs with the same anion and different cation were compared. In general, the cation toxicity for other microorganisms has been higher for ILs containing aromatic cations, such as imidazolium and pyridinium cations, in comparison to nonaromatic cations, e.g., pyrrolidinium. A higher hydrophobic character of aromatic cations could increase the possibility of interaction with the cell membrane $[81,82,85]$. Furthermore, the planarity of the cation ring in imidazolium and pyridinium appeared to be also a relevant parameter for increasing IL toxicity, as reported in [90]. This fact could be due to the lower steric hindrance of the aromatic cation, which might favor the interactions with the lipidic membrane to a greater extent. For S. cerevisiae, a high toxicity was found for pyridinium and imidazolium cations compared with pyrrolidinium cations for the series $\left[\mathrm{Bmpy}^{+}\right]\left[\mathrm{dca}^{-}\right](R I=1.1 \mathrm{~cm}),\left[\mathrm{Bmim}^{+}\right]\left[\mathrm{dca}^{-}\right](R I=0.6 \mathrm{~cm})$ and $\left[\mathrm{BMPyr}^{+}\right][\mathrm{dca}]$ $(R I=0.4 \mathrm{~cm})$ and also for the series $\left[\mathrm{Epy}^{+}\right]\left[\mathrm{NTf}^{-}\right](R I=0.6 \mathrm{~cm}),\left[\mathrm{Emim}^{+}\right]\left[\mathrm{NTf}^{-}\right](R I=0.1 \mathrm{~cm})$ and $\left[\mathrm{Empyr}^{+}\right]\left[\mathrm{NTf}^{-}\right](\mathrm{RI}=0.0 \mathrm{~cm})$. The IL $\left[\mathrm{Bmpy}^{+}\right]\left[\mathrm{BF}_{4}^{-}\right](R I=1.4 \mathrm{~cm})$ was also found to be more toxic 
than $\left[\mathrm{Bmim}^{+}\right]\left[\mathrm{BF}_{4}^{-}\right](R I=0.7)$ to S. cerevisiae. On the contrary, the toxicity of $\left[\mathrm{Bmim}^{+}\right]\left[\mathrm{NTf}^{-}\right]$was lower than the toxicity of $\left[\mathrm{BMPyr}^{+}\right]\left[\mathrm{NTf}^{-}\right]$. Similar results were reported for Shewanella [89].

On the other hand, the toxicity of imidazolium cations ranges from very high for $\left[\mathrm{Omin}^{+}\right]\left[\mathrm{dca}^{-}\right]$ $(R I=2 \mathrm{~cm})$, which is an IL with a long alkyl chain, to zero $(R I=0.0 \mathrm{~cm})$ as in the case of the IL $\left[\mathrm{OHPmim}{ }^{+}\right]\left[\mathrm{NO}_{3}{ }^{-}\right]$, whose structure contains a hydrophilic substituent. It is worth noting that $\left[\mathrm{Bmim}^{+}\right]\left[\mathrm{NO}_{3}{ }^{-}\right]$was also biocompatible toward S. cerevisiae, maybe due to the presence of the nitrate anion in its structure. Existing studies on the toxicity of imidazolium-based ILs to S. cerevisiae were performed taking into account the cell growth in the presence of $\left[\mathrm{Bmim}^{+}\right]\left[\mathrm{PF}_{6}{ }^{-}\right],\left[\mathrm{Bmim}^{+}\right]\left[\mathrm{BF}_{4}^{-}\right]$and hexane. A slight reduction in the growth was observed with $\left[\mathrm{Bmim}^{+}\right]\left[\mathrm{PF}_{6}{ }^{-}\right]$compared to the control without IL. The growth in the presence of $\left[\mathrm{Bmim}^{+}\right]\left[\mathrm{BF}_{4}{ }^{-}\right]$was lower than in $\left[\mathrm{Bmim}^{+}\right]\left[\mathrm{PF}_{6}{ }^{-}\right]$, and the growth in hexane was much lower than in $\left[\mathrm{Bmim}^{+}\right]\left[\mathrm{BF}_{4}^{-}\right]$[91]. Furthermore, it was demonstrated that the presence of $\left[\mathrm{Bmim}^{+}\right]\left[\mathrm{Cl}^{-}\right]$during an ethanol fermentation process inhibits yeast growth [22]. These results are in good agreement with those found in the agar well diffusion test since the RI was $0.4,0.7$ and $0.6 \mathrm{~cm}$ for $\left[\mathrm{Bmim}^{+}\right]\left[\mathrm{PF}_{6}^{-}\right],\left[\mathrm{Bmim}^{+}\right]\left[\mathrm{BF}_{4}^{-}\right]$and $\left[\mathrm{Bmim}^{+}\right]\left[\mathrm{Cl}^{-}\right]$, respectively.

For pyridinium-based ILs, the toxicity varies from an $R I$ equal to $1.4 \mathrm{~cm}\left(\left[\mathrm{bmpy}^{+}\right]\left[\mathrm{BF}^{-}\right]\right)$to $0.4 \mathrm{~cm}\left(\left[\mathrm{mmpy}^{+}\right]\left[\mathrm{MeSO}_{4}^{-}\right]\right)$. All ILs based on the pyridinium cation were fully biocompatible with S. Cerevisiae. Regarding the pyrrolidinium-based ILs assayed, lower toxicity values were obtained, $\left[\right.$ Empyr $\left.^{+}\right]\left[\mathrm{NTf}^{-}\right]$being fully biocompatible with $S$. cerevisiae $(R I=0.0 \mathrm{~cm})$. The only piperidinium IL tested $\left(\left[\mathrm{Bmpi}^{+}\right]\left[\mathrm{NTf}^{-}\right]\right)$was also biocompatible with the yeast $(R I=0.0 \mathrm{~cm})$, which might be due to the nonaromatic character and the presence of bis (trifluoromethylsulfonyl) imide as counteranion.

For ILs containing the ammonium cation, different toxicity values were found depending on the alkyl chain length of the cation and the type of anion. The toxicity values ranged from the highest toxicity for $\left[\mathrm{C}_{\mathrm{EGG}}{ }^{+}\right]\left[\mathrm{MeSO}_{4}{ }^{-}\right],\left[\mathrm{T} 2 \mathrm{EG}^{+}\right]\left[\mathrm{MeSO}_{4}{ }^{-}\right],(R I=1 \mathrm{~cm})$ to the lowest toxicity for $\left[\mathrm{N}_{8881}{ }^{+}\right]$ $\left[\mathrm{NTf}^{-}\right]$and $\left[\mathrm{Chol}^{+}\right]\left[\mathrm{H}_{2} \mathrm{PO}_{4}^{-}\right](R I=0.0 \mathrm{~cm})$. The anion $\left[\mathrm{NTf2}{ }^{-}\right]$is present again in ILs with low toxicity, maybe due to its structure or its low water solubility. The IL $\left[\mathrm{Chol}^{+}\right]\left[\mathrm{H}_{2} \mathrm{PO}_{4}^{-}\right]$contains a cation with heteroatoms and short alkyl chains. Other research works report that this IL is biocompatible with Shewanella sp. and even with the enzyme laccase, with overactivity reached in the presence of this IL [31,89]. Santos et al. [92] determined the maximum nontoxic concentration of choline-based ILs to S. cerevisiae finding significant biocompatibility when the ILs were water-soluble. The biocompatibility with choline-based hydrophilic IL was lower. All these results are in good agreement with those reported in the present study.

In the case of the phosphonium family, it was found that long alkyl chains promote higher toxic effects toward the bacterium Vibrio fisheri [83], following the 'side-chain effect' mentioned above. The toxicity values for phosphonium-based IL toward $S$. cerevisiae ranged from $R I=1.5 \mathrm{~cm}\left(\left[\mathrm{P}_{6,6,6,6,14}{ }^{+}\right]\right.$ $\left.\left[\mathrm{C}_{9} \mathrm{COO}^{-}\right]\right)$to $\mathrm{RI}=0.2 \mathrm{~cm}\left(\left[\mathrm{P}_{6,6,6,14^{+}}\right]\left[\mathrm{Cl}^{-}\right]\right)$. In the existing literature, the toxicity of $\left[\mathrm{P}_{4,4,4,1}{ }^{+}\right]\left[\mathrm{CH}_{3} \mathrm{SO}_{4}{ }^{-}\right]$ was obtained by determining the maximum nontoxic concentration of the IL for $S$. cerevisiae, resulting in toxicity toward S. cerevisiae [92]. The same result was obtained in this work by using the agar well diffusion test.

On the other hand, the morpholinum-based IL was found to be biocompatible with S. cerevisiae, which might be due to the inclusion of a heteroatom in the imidazolium ring and also to the low alkyl chain constituent of the aromatic ring. Finally, only a sulfonium-based IL was assessed, $\left[\mathrm{S}_{\left.2,2,2^{+}\right]}\right]$ $\left[\mathrm{NTf}^{-}\right]$, which proved to be biocompatible with S. cerevisiae. These results might be related to the nature of its counteranion.

\subsection{Effect of the Ionic Liquid Anion on Toxicity toward S. cerevisiae}

The effect of the anion composition on the IL toxicity was analyzed by comparing ILs with different anions and the same cation. Several authors have reported that the toxicity of ILs on several microorganisms is directly related to the cation nature, while the anion seems to modulate the toxicity to some extent and in specific cases [77-80,93]. This behavior was observed in several ILs in which the toxicity values were similar when sharing the same cation but contain different anions. For example, 
this occurs when comparing $\left[\mathrm{Bmim}^{+}\right]\left[\mathrm{Cl}^{-}\right](R I=0.6 \mathrm{~cm}),\left[\mathrm{Bmim}^{+}\right]\left[\mathrm{BF}_{4}^{-}\right](R I=0.7 \mathrm{~cm}),\left[\mathrm{Bmim}^{+}\right]$ $\left[\mathrm{dca}^{-}\right](R I=0.6 \mathrm{~cm}),\left[\mathrm{Bmim}^{+}\right]\left[\mathrm{HSO}_{4}^{-}\right](R I=0.5 \mathrm{~cm}),\left[\mathrm{Bmim}^{+}\right]\left[\mathrm{PF}_{6}{ }^{-}\right](R I=0.4 \mathrm{~cm})$ and $\left[\mathrm{Bmim}^{+}\right]$ $\left[\mathrm{SCN}^{-}\right](R I=0.8 \mathrm{~cm})$. However, the radius of inhibition for other $\left[\mathrm{Bmim}^{+}\right]$-based ILs can greatly differ, for instance, in the cases of $\left[\mathrm{Bmim}^{+}\right]\left[\mathrm{NTf}^{-}\right](R I=0.0 \mathrm{~cm})$ and $\left[\mathrm{Bmim}^{+}\right]\left[\mathrm{MeCOO}^{-}\right](R I=1 \mathrm{~cm})$. This could be explained by the contribution of other factors to the toxicity values, such as anion nature, IL solubility, or the synergy effect between anion and cation nature. Synergy effects between the anion and the cation can occur, which make the complete isolation of individual anion and cation contributions difficult; and, as mentioned above, IL toxicity has been mainly correlated to the cation than to the anion. Another important consideration of the anion is that those with high lipophilicity or susceptible to hydrolysis could offer partially drastic effects. $\left[\mathrm{PF}_{6}{ }^{-}\right]$could be included in this group, since it is well established the instability of ionic liquids containing this anion toward hydrolysis in contact with moisture-forming volatiles, e.g., $\mathrm{HF}, \mathrm{POF}_{3}$, etc., which might pose potentially hazardous effects [94-96]; [NTf2 ${ }^{-}$] could also be included due to its hydrophobicity, which is even higher than $\left[\mathrm{PF}_{6}{ }^{-}\right][33,96]$.

For a better understanding of the influence of the anion nature on IL toxicity, an anion sequence for different cation families is presented in Table 7 in terms of RI. As can be seen, similar toxicity values were found within the same cation family; e.g., from $\left[\mathrm{PF}_{6}{ }^{-}\right]$to $\left[\mathrm{BF}_{4}{ }^{-}\right]$within the $\left[\mathrm{Bmim}^{+}\right]$ family, from [TMPPhos $\left.{ }^{-}\right]$to $\left[\mathrm{BF}_{4}^{-}\right]$within the $\left[\mathrm{P}_{6,6,6,14^{+}}\right]$family, the full $\left[\mathrm{HOPmim}{ }^{+}\right]$family and the full $\left[\mathrm{Epy}^{+}\right]$family. As commented above, this behavior could be explained due to the strong cation influence on the IL toxicity. Furthermore, anions were also found with a high influence on the toxicity, such as [NTf2- ${ }^{-}$, which always shows low toxicity regardless of the IL cation. It could be explained by the nature of the bistriflimide anion or because this anion confers low solubility to the overall IL. Sendovsky et al. [11] also found that $\left[\mathrm{NTf}^{-}\right]$was more biocompatible than $\left[\mathrm{PF}_{6}{ }^{-}\right]$and $\left[\mathrm{BF}_{4}{ }^{-}\right]$, which supports the results obtained in the present work. Other anions with high influence were carboxylates, which were the most toxic within the $\left[\mathrm{Bmim}^{+}\right]$and $\left[\mathrm{P}_{6,6,6,14}{ }^{+}\right]$families. However, when this anion is hydroxylated, the IL became less toxic as can be seen for the $\left[\mathrm{Bmim}^{+}\right]$family (see Table 7). Wood et al. [20] tested the toxicity of imidazolium cations combined with halides $\left(\left[\mathrm{Cl}^{-}\right],\left[\mathrm{Br}^{-}\right]\right)$toward E. coli. The $\left[\mathrm{Emim}^{+}\right]$and $\left[\mathrm{Bmim}^{+}\right]$chlorides and bromides did not produce visible inhibition zones in the agar diffusion test but inhibition zones were observed when the alkyl chain increased up to six and eight carbons. In the case of S. Cerevisiae, the $\left[\mathrm{Cl}^{-}\right]$anion yielded high toxicity when combined with other imidazolium cations such as $\left[\mathrm{Bmim}^{+}\right]$and $\left[\mathrm{Hmim}^{+}\right]$. However, the combination of $\left[\mathrm{Cl}^{-}\right]$with an imidazolium cation with a hydroxyl alkyl chain substituent $\left.\left(\mathrm{HOPmim}^{+}\right]\right)$reduced dramatically the IL toxicity. On the other hand, for $\left[\mathrm{Cl}^{-}\right]$combined with ammonium $\left(\left[\mathrm{N}_{8,8,8,1}{ }^{+}\right]\right)$, high toxicity was found. Cornmell et al. [97] reported that the IL $\left[\mathrm{N}_{1,8,8,8}{ }^{+}\right]\left[\mathrm{Cl}^{-}\right]$inhibits the growth of E. coli.

Table 7. Sequence of anion toxicity for each cation family.

\begin{tabular}{|c|c|c|c|c|c|c|c|c|c|c|c|c|}
\hline \multirow{2}{*}{$\begin{array}{l}\begin{array}{c}\text { Cation } \\
\text { Family }\end{array} \\
{\left[\mathrm{Bmim}^{+}\right]}\end{array}$} & \multicolumn{12}{|c|}{ Anion Sequence from Lower to Higher Toxicity and Radius of Inhibition (RI) } \\
\hline & $\begin{array}{c}\left.\text { [NTf2 }^{-}\right] \\
(0)\end{array}$ & $\begin{array}{c}{\left[\mathrm{NO}_{3}{ }^{-}\right]} \\
(0)\end{array}$ & $\begin{array}{c}{\left[\mathrm{CH}_{2} \mathrm{OHCOO}^{-}\right]} \\
(0.3)\end{array}$ & $\begin{array}{c}{\left[\mathrm{PF}_{6}{ }^{-}\right]} \\
(0.4)\end{array}$ & $\begin{array}{c}{\left[\mathrm{HSO}_{4}{ }^{-}\right]} \\
(0.5)\end{array}$ & $\begin{array}{c}{\left[\mathrm{Cl}^{-}\right]} \\
(0.6)\end{array}$ & $\begin{array}{c}{\left[\mathrm{dca}^{-}\right]} \\
(0.6)\end{array}$ & $\begin{array}{c}{\left[\mathrm{BF}_{4}^{-}\right]} \\
(0.7)\end{array}$ & $\begin{array}{c}{\left[\mathrm{SCN}^{-}\right]} \\
(0.8)\end{array}$ & $\begin{array}{c}\left.\text { [TFES }^{-}\right] \\
(0.9)\end{array}$ & $\begin{array}{c}{\left[\mathrm{CH}_{3} \mathrm{COO}^{-}\right]} \\
\text {(1) }\end{array}$ & $\begin{array}{c}{\left[\mathrm{MeCOO}_{2}^{-}\right]} \\
\text {(1) }\end{array}$ \\
\hline$\left[\mathrm{P}_{6,6,6,14}{ }^{+}\right]$ & $\begin{array}{c}\left.\text { [NTf2 }^{-}\right] \\
(0.2)\end{array}$ & $\begin{array}{c}{\left[\mathrm{Cl}^{-}\right]} \\
(0.2) \\
\end{array}$ & $\begin{array}{c}\left.\text { [TMPPhos }^{-}\right] \\
(0.5)\end{array}$ & $\begin{array}{c}{\left[\mathrm{dca}^{-}\right]} \\
(0.5)\end{array}$ & $\begin{array}{c}{\left[\mathrm{BF}_{4}^{-}\right]} \\
(0.6) \\
\end{array}$ & $\begin{array}{c}{\left[\mathrm{Br}^{-}\right]} \\
(0.9) \\
\end{array}$ & $\begin{array}{c}{\left[\mathrm{C}_{9} \mathrm{COO}^{-}\right]} \\
(1.5) \\
\end{array}$ & & & & & \\
\hline$\left[\mathrm{Omim}^{+}\right]$ & $\begin{array}{c}\left.\text { [NTf2 }^{-}\right] \\
(0.3)\end{array}$ & $\begin{array}{c}{\left[\mathrm{PF}_{6}^{-}\right]} \\
(0.5)\end{array}$ & $\begin{array}{c}{\left[\mathrm{BF}_{4}^{-}\right]} \\
(1.3) \\
\end{array}$ & $\begin{array}{c}{\left[\mathrm{dca}^{-}\right]} \\
(2)\end{array}$ & & & & & & & & \\
\hline$\left[\mathrm{HOPmim}^{+}\right]$ & $\begin{array}{c}{\left[\mathrm{NO}_{3}{ }^{-}\right]} \\
(0)\end{array}$ & $\begin{array}{c}{\left[\mathrm{dca}^{-}\right]} \\
(0)\end{array}$ & $\begin{array}{c}{\left[\mathrm{Cl}^{-}\right]} \\
(0.1) \\
\end{array}$ & & & & & & & & & \\
\hline$\left[\mathrm{Hmim}^{+}\right]$ & $\begin{array}{c}{\left[\mathrm{dca}^{-}\right]} \\
(0.5)\end{array}$ & $\begin{array}{c}{\left[\mathrm{Cl}^{-}\right]} \\
(1.3)\end{array}$ & & & & & & & & & & \\
\hline$\left[\mathrm{Emim}^{+}\right]$ & $\begin{array}{c}\left.\text { [NTf2 }^{-}\right] \\
(0.1)\end{array}$ & & & & & & & & & & & \\
\hline$\left[\mathrm{MOMmim}^{+}\right]$ & $\begin{array}{c}{\left[\mathrm{BF}_{4}^{-}\right]} \\
(0.2) \\
\end{array}$ & $\begin{array}{c}{\left[\mathrm{PF}_{6}{ }^{-}\right]} \\
(2)\end{array}$ & & & & & & & & & & \\
\hline$\left[\mathrm{MOEmim}^{+}\right]$ & $\begin{array}{c}{\left[\mathrm{BF}_{4}^{-}\right]} \\
(0.7) \\
\end{array}$ & $\begin{array}{c}{\left[\mathrm{dca}^{-}\right]} \\
(1)\end{array}$ & & & & & & & & & & \\
\hline$\left[\mathrm{BMPy}^{+}\right]$ & $\begin{array}{c}{\left[\mathrm{dca}^{-}\right]} \\
(1.1) \\
\end{array}$ & $\begin{array}{c}{\left[\mathrm{BF}_{4}^{-}\right]} \\
(1.4) \\
\end{array}$ & & & & & & & & & & \\
\hline$\left[\mathrm{EPy}^{+}\right]$ & $\begin{array}{c}\left.\text { [NTf2 }^{-}\right] \\
(0.5)\end{array}$ & $\begin{array}{c}{\left[\mathrm{EtSO}_{4}^{-}\right]} \\
(0.5)\end{array}$ & & & & & & & & & & \\
\hline
\end{tabular}


Table 7. Cont

\begin{tabular}{|c|c|c|}
\hline $\begin{array}{l}\text { Cation } \\
\text { Family }\end{array}$ & & Anion Sequence from Lower to Higher Toxicity and Radius of Inhibition $(R I)$ \\
\hline$\left[\mathrm{N}_{8,8,8,1}{ }^{+}\right]$ & $\begin{array}{cc}\left.\mathrm{NTf2}^{-}\right] & {\left[\mathrm{Cl}^{-}\right]} \\
(0) & 0.6\end{array}$ & \\
\hline$\left[\mathrm{Chol}^{+}\right]$ & $\begin{array}{cc}{\left[\mathrm{H}_{2} \mathrm{PO}_{4}^{-}\right]} & {\left[\mathrm{NTf2}^{-}\right]} \\
(0) & (0.1)\end{array}$ & \\
\hline
\end{tabular}

\subsection{Mechanisms of IL toxicity}

Relatively few mechanisms have been suggested to explain the toxicity of ILs towards microorganisms, but membrane disruption is considered the most common $[98,99]$. The ability of the ILs to disrupt the cell wall of different microorganisms seems to be due to their hydrophobicity, caused by the length of the alkyl side chain of the cation or the presence of aromatic cations, which is in line with the results obtained in the present work.

Furthermore, the inclusion of a heteroatom such as oxygen leads to reduce the hydrophobicity of the IL and thus toxicity. Weuster-Botz [100] studied the membrane integrity of S. cerevisiae cells after $5 \mathrm{~h}$ of exposure to biphasic systems comparing pure buffer and $\left[\mathrm{Bmim}^{+}\right]\left[\mathrm{PF}_{6}{ }^{-}\right],\left[\mathrm{Bmim}^{+}\right]$ $\left[\mathrm{NTf}^{-}\right]$and $\left[\mathrm{Omim}^{+}\right]\left[\mathrm{NTf}^{-}\right]$. The membrane integrity of $S$. cerevisiae with the ILs was similar to that in aqueous media $(90 \%)$. Slightly higher membrane integrity was found for [Omim $\left.{ }^{+}\right]\left[\mathrm{NTf}^{-}\right]$. Those results are in concordance with the results showed in the present work, in which $\left[\mathrm{Bmim}^{+}\right]$ $\left[\mathrm{NTf} 2^{-}\right]$and $\left[\mathrm{Omim}^{+}\right]\left[\mathrm{NTf}_{2}^{-}\right]$have been classified as biocompatible, and $\left[\mathrm{Bmim}^{+}\right]\left[\mathrm{PF}_{6}{ }^{-}\right]$as low toxic. Other molecular mechanisms cannot be excluded when explaining the toxicity of ILs. Dickinson and Piotrowski et al. [101] studied the toxicity mechanism of $\left[\mathrm{Emim}^{+}\right]\left[\mathrm{Cl}^{-}\right],\left[\mathrm{Bmim}^{+}\right]\left[\mathrm{Cl}^{-}\right]$and $\left[\mathrm{Emim}^{+}\right]\left[\mathrm{CH}_{3} \mathrm{COO}^{-}\right]$. They found that these ILs likely target mitochondria. High-throughput chemical proteomics showed the effects of ILs on mitochondrial protein levels. ILs induced abnormal mitochondrial morphology, as well as, altered the polarization of mitochondrial membrane potential, similar to valinomycin.

\subsection{Ionic Liquids Biocompatible with S. cerevisiae}

The agar well diffusion test can serve as an easy and quick decision-making tool when it comes to choosing sustainable ILs for biotechnological applications involving $S$. cerevisiae. In this case, ILs are deemed as biocompatible with $S$. cerevisiae when the radius of inhibition is equal to zero. In this sense, those classified as biocompatible are $\left[\mathrm{Bmim}^{+}\right]\left[\mathrm{NO}_{3}{ }^{-}\right]$in which the low toxicity could be explained by the anion; $\left[\mathrm{HOPmim}{ }^{+}\right]\left[\mathrm{NO}_{3}{ }^{-}\right]$due to the anion and the hydroxyl imidazolium substituent; $\left[\mathrm{Bmim}^{+}\right]$ [NTf2 $\left.2^{-}\right],\left[\mathrm{N}_{8,8,8,1^{+}}\right]\left[\mathrm{NTf}^{-}\right]$and $\left[\mathrm{S}_{2,2,2^{+}}\right]$[NTf2 $\left.{ }^{-}\right]$in which the bistriflimide anion strongly contributes to the biocompatibility; $\left[\mathrm{EMPyr}^{+}\right]\left[\mathrm{NTf}^{-}\right]$and $\left[\mathrm{BMPi}^{+}\right]\left[\mathrm{NTf}^{-}\right]$due to the anion and the nonaromatic structure of the cation; $\left[\mathrm{Moxa}^{+}\right]\left[\mathrm{MeSO}_{4}{ }^{-}\right]$due to the inclusion of the oxygen heteroatom in the imidazolium ring, which consequently increases its polarity, and $\left[\mathrm{Chol}^{+}\right]\left[\mathrm{H}_{2} \mathrm{PO}_{4}^{-}\right]$due to the hydroxyl short alkyl chain length and the nature of the anion. It is important to highlight that the studies on the toxicity of ILs in yeast are still low, but the few that exist corroborate the results reported in the current work. Sendovski et al. [11] also found that $\left[\mathrm{Bmim}^{+}\right]$[NTf2 $\left.{ }^{-}\right]$and $\left[\mathrm{N}_{8,8,8,1}{ }^{+}\right]\left[\mathrm{NTf} 2^{-}\right]$were biocompatible with $S$. cerevisiae. It is also important to note that the agar well diffusion method for the assessment of IL toxicity toward S. cerevisiae has been validated not only by comparison with other methods in previous works of our research group ([19]) but also with the results reported by other authors in this field, as commented throughout this work.

\section{Conclusions}

This work assesses the toxicity of a high number of ionic liquids toward S. cerevisiae using the agar well diffusion test. This method enables the easy and quick analysis of their biocompatibility toward S. cerevisiae with the aim to open up new synergy technologies between S. cerevisiae and ILs. With this method, nine fully biocompatible ILs toward S. cerevisiae have been identified, including $\left[\mathrm{Bmim}^{+}\right.$] 
$\left[\mathrm{NO}_{3}{ }^{-}\right],\left[\mathrm{HOPmim}^{+}\right]\left[\mathrm{NO}_{3}{ }^{-}\right],\left[\mathrm{Bmim}^{+}\right]\left[\mathrm{NTf}^{-}\right],\left[\mathrm{N}_{8,8,8,1}{ }^{+}\right]\left[\mathrm{NTf}^{-}\right],\left[\mathrm{S}_{2,2,2^{+}}\right]\left[\mathrm{NTf}^{-}\right],\left[\mathrm{EMPyr}^{+}\right]\left[\mathrm{NTf}^{-}\right]$, $\left[\mathrm{BMPi}^{+}\right]\left[\mathrm{NTf}^{-}\right],\left[\mathrm{Moxa}^{+}\right]\left[\mathrm{MeSO}_{4}{ }^{-}\right]$and $\left[\mathrm{Chol}^{+}\right]\left[\mathrm{H}_{2} \mathrm{PO}_{4}^{-}\right]$. The results obtained also allowed us to establish several toxicity-structure relationships which could even help to make important predictions about IL toxicity, without further experimentation. Thus, it was observed that an increase in the alkyl chain length in cations such as imidazolium or pyridinium involves an increase in the hydrophobicity of the ILs and therefore, an increase of their toxicity. Furthermore, the toxicity is mainly determined by the cation but, certain anions have a strong influence on IL toxicity as in the case of the [NTf2 ${ }^{-}$] anion, which dramatically reduces the toxicity of the IL towards S. cerevisiae.

Author Contributions: Conceptualization, F.M., A.P.d.1.R. and F.J.H.-F.; Data curation, F.M., V.O.-M. and M.J.S.-G.; Formal analysis, F.M. and F.J.H.-F.; Funding acquisition, A.P.d.1.R. and F.J.H.-F.; Investigation, F.M., A.P.d.1.R., V.O.-M., M.J.S.-G., J.H.-F. and F.J.H.-F.; Methodology, F.M. and F.J.H.-F.; Project administration, A.P.d.1.R. and F.J.H.-F.; Resources, F.M.; Supervision, A.P.d.1.R. and F.J.H.-F.; Writing—original draft, F.M., V.O.-M., M.J.S.-G. and F.J.H.-F.; Writing-review \& editing, F.M., V.O.-M., M.J.S.-G. and J.H.-F. All authors have read and agreed to the published version of the manuscript.

Funding: This work has been funded by the Spanish Ministry of Economy and Competitiveness (MINECO) (Grant number: RTI2018-099011-B-I00) and Séneca Foundation (Grant number: 20957/PI/18).

Acknowledgments: F. Missoun's postdoctoral stay was financed by the Erasmus Mundus program action 2: EU;MARE NOSTRUM (204195-EM-1-2011-1-ES-ERA MUNDUS-EMA21).

Conflicts of Interest: The authors declare no conflict of interest.

\section{References}

1. Lian, J.; Mishra, S.; Zhao, H. Recent advances in metabolic engineering of Saccharomyces cerevisiae: New tools and their applications. Metab. Eng. 2018. [CrossRef] [PubMed]

2. Fernandez-Moya, R.; Da Silva, N.A. Engineering Saccharomyces cerevisiae for high-level synthesis of fatty acids and derived products. FEMS Yeast Res. 2017. [CrossRef] [PubMed]

3. Lian, J.; Zhao, H. Recent advances in biosynthesis of fatty acids derived products in Saccharomyces cerevisiae via enhanced supply of precursor metabolites. J. Ind. Microbiol. Biotechnol. 2014. [CrossRef] [PubMed]

4. Zhang, Y.; Nielsen, J.; Liu, Z. Engineering yeast metabolism for production of terpenoids for use as perfume ingredients, pharmaceuticals and biofuels. FEMS Yeast Res. 2017. [CrossRef]

5. Sánchez, S.; Lozano, L.J.; Godínez, C.; Juan, D.; Pérez, A.; Hernández, F.J. Carob pod as a feedstock for the production of bioethanol in Mediterranean areas. Appl. Energy 2010. [CrossRef]

6. Generoso, W.C.; Schadeweg, V.; Oreb, M.; Boles, E. Metabolic engineering of Saccharomyces cerevisiae for production of butanol isomers. Curr. Opin. Biotechnol. 2015. [CrossRef]

7. Wang, G.; Huang, M.; Nielsen, J. Exploring the potential of Saccharomyces cerevisiae for biopharmaceutical protein production. Curr. Opin. Biotechnol. 2017. [CrossRef]

8. Hernández-Fernández, F.J.; De Los Ríos, A.P.; Lozano-Blanco, L.J.; Godínez, C. Biocatalytic ester synthesis in ionic liquid media. J. Chem. Technol. Biotechnol. 2010. [CrossRef]

9. Baicha, Z.; Salar-García, M.J.; Ortiz-Martínez, V.M.; Hernández-Fernández, F.J.; de los Ríos, A.P.; Maqueda Marín, D.P.; Collado, J.A.; Tomás-Alonso, F.; El Mahi, M. On the selective transport of nutrients through polymer inclusion membranes based on ionic liquids. Processes 2019, 7, 544. [CrossRef]

10. Li, Q.; He, Y.C.; Xian, M.; Jun, G.; Xu, X.; Yang, J.M.; Li, L.Z. Improving enzymatic hydrolysis of wheat straw using ionic liquid 1-ethyl-3-methyl imidazolium diethyl phosphate pretreatment. Bioresour. Technol. 2009. [CrossRef]

11. Sendovski, M.O.R.; Nir, N.; Fishman, A. Bioproduction of 2-Phenylethanol in a Biphasic Ionic liquid Aqueous system. J. Agric. Food Chem. 2010. [CrossRef] [PubMed]

12. Shi, Y.G.; Fang, Y.; Ren, Y.P.; Wu, H.P.; Guan, H.L. Effect of ionic liquid [BMIM][PF6] on asymmetric reduction of ethyl 2-oxo-4-phenylbutyrate by Saccharomyces cerevisiae. J. Ind. Microbiol. Biotechnol. 2008. [CrossRef] [PubMed]

13. Thuy Pham, T.P.; Cho, C.W.; Yun, Y.S. Environmental fate and toxicity of ionic liquids: A review. Water Res. 2010. [CrossRef] [PubMed]

14. Zhao, D.; Liao, Y.; Zhang, Z.D. Toxicity of ionic liquids. Clean Soil Air Water 2007. [CrossRef] 
15. Kang, X.; Chen, Z.; Zhao, Y. Assessing the ecotoxicity of ionic liquids on Vibrio fischeri using electrostatic potential descriptors. J. Hazard. Mater. 2020, 397, 122761. [CrossRef] [PubMed]

16. Mena, I.F.; Diaz, E.; Palomar, J.; Rodriguez, J.J.; Mohedano, A.F. Cation and anion effect on the biodegradability and toxicity of imidazolium- and choline-based ionic liquids. Chemosphere 2020, 240, 124947. [CrossRef]

17. Delgado-Mellado, N.; Ayuso, M.; Villar-Chavero, M.M.; García, J.; Rodríguez, F. Ecotoxicity evaluation towards Vibrio fischeri of imidazolium- and pyridinium-based ionic liquids for their use in separation processes. SN Appl. Sci. 2019, 1, 896. [CrossRef]

18. Jafari, M.; Keshavarz, M.H.; Salek, H. A simple method for assessing chemical toxicity of ionic liquids on Vibrio fischeri through the structure of cations with specific anions. Ecotoxicol. Environ. Saf. 2019, 182, 109429. [CrossRef]

19. Peréz de los Ríos, A.; Hernandez-Fernandez, F.J.; Zapata Henríquez, P.A.; Missoun, F.; Hernández Fernández, J.; Ortiz Martínez, V.M.; Salar García, M.J.; Lozano Blanco, L.J.; Godinez, C. Keys for new bioethanol production processes by fermentation and ionic liquid extraction. ACS Sustain. Chem. Eng. 2017. [CrossRef]

20. Wood, N.; Ferguson, J.L.; Gunaratne, H.Q.N.; Seddon, K.R.; Goodacre, R.; Stephens, G.M. Screening ionic liquids for use in biotransformations with whole microbial cells. Green Chem. 2011, 13, 1843-1851. [CrossRef]

21. Ventura, S.P.M.; de Barros, R.L.F.; Sintra, T.; Soares, C.M.F.; Lima, Á.S.; Coutinho, J.A.P. Simple screening method to identify toxic/non-toxic ionic liquids: Agar diffusion test adaptation. Ecotoxicol. Environ. Saf. 2012, 83, 55-62. [CrossRef] [PubMed]

22. Zhu, S.; Yu, P.; Lei, M.; Tong, Y.; Zheng, L.; Zhang, R.; Ji, J.; Chen, Q.; Wu, Y. Investigation of the toxicity of the ionic liquid 1-butyl-3- methylimidazolium chloride to saccharomyces cerevisiae AY93161 for lignocellulosic ethanol production. Pol. J. Chem. Technol. 2013, 15, 94-98. [CrossRef]

23. Wood, N.; Stephens, G. Accelerating the discovery of biocompatible ionic liquids. Phys. Chem. Chem. Phys. 2010, 12, 1670-1674. [CrossRef] [PubMed]

24. José Santos Júnior, R.; Andrade Batista, R.; Alves Rodrigues, S.; Xavier Filho, L.; Silva Lima, Á. Antimicrobial Activity of Broth Fermented with Kombucha Colonies. J. Microb. Biochem. Technol. 2009. [CrossRef]

25. Silva, K.R.; Rodrigues, S.A.; Filho, L.X.; Lima, Á.S. Antimicrobial activity of broth fermented with kefir grains. Appl. Biochem. Biotechnol. 2009, 152, 316-325. [CrossRef]

26. Magaldi de, S.; Mata, S.; Camero, T.; Marcano, C.; Hartung, C. Determinación de la sensibilidad antifúngica en agentes de cromomicosis mediante la técnica de los pozos de difusión. Antibiot. Infecc. 1999, 7, 17-20.

27. Magaldi, S.; Camero, T.; Mata, S.; Ríos, A. Pruebas de sensibilidad de Candida albicans frente a los antimicóticos de uso comercial. Bol. Soc. Venez. Microbiol. 1998, 18, 16-20.

28. Ismail Hossain, M.; El-Harbawi, M.; Noaman, Y.A.; Bustam, M.A.B.; Alitheen, N.B.M.; Affandi, N.A.; Hefter, G.; Yin, C.Y. Synthesis and anti-microbial activity of hydroxylammonium ionic liquids. Chemosphere 2011. [CrossRef]

29. Dharaskar, S.A.; Varma, M.N.; Shende, D.Z.; Yoo, C.K.; Wasewar, K.L. Synthesis, characterization and application of 1-butyl-3 methylimidazolium chloride as green material for extractive desulfurization of liquid fuel. Sci. World J. 2013. [CrossRef]

30. Dharaskar, S.A.; Wasewar, K.L.; Varma, M.N.; Shende, D.Z.; Yoo, C.K. Synthesis, characterization and application of 1-butyl-3-methylimidazolium tetrafluoroborate for extractive desulfurization of liquid fuel. Arab. J. Chem. 2016. [CrossRef]

31. Galai, S.; De Los Ríos, A.P.; Hernández-Fernández, F.J.; Haj Kacem, S.; Tomas-Alonso, F. Over-activity and stability of laccase using ionic liquids: Screening and application in dye decolorization. RSC Adv. 2015. [CrossRef]

32. Freire, M.G.; Santos, L.M.N.B.F.; Fernandes, A.M.; Coutinho, J.A.P.; Marrucho, I.M. An overview of the mutual solubilities of water-imidazolium-based ionic liquids systems. Fluid Phase Equilib. 2007. [CrossRef]

33. Carda-Broch, S.; Berthod, A.; Armstrong, D.W. Solvent properties of the 1-butyl-3-methylimidazolium hexafluorophosphate ionic liquid. Anal. Bioanal. Chem. 2003. [CrossRef] [PubMed]

34. Iolitec. Technical Data Sheet 1-Methyl-3-Octylimidazolium Hexafluorophosphate; Iolitec: Heilbronn, Germany, 2014.

35. Dharaskar, S.A.; Wasewar, K.L.; Varma, M.N.; Shende, D.Z. Synthesis, characterization, and application of 1-butyl-3-methylimidazolium thiocyanate for extractive desulfurization of liquid fuel. Environ. Sci. Pollut. Res. 2016. [CrossRef] 
36. Papaiconomou, N.; Yakelis, N.; Salminen, J.; Bergman, R.; Prausnitz, J.M. Synthesis and properties of seven ionic liquids containing 1-methyl-3-octylimidazolium or 1-butyl-4-methylpyridinium cations. J. Chem. Eng. Data 2006. [CrossRef]

37. Santa Cruz Biotechnology, Inc. 1,2,3-Trimethylimidazolium Methyl Sulfate; Santa Cruz Biotechnology, Inc.: Dallas, TX, USA, 2012.

38. Chemical Book 1-Ethyl-3-Methylimidazolium Trifluoromethanesulfonate. Available online: https://www. chemicalbook.com/ChemicalProductProperty_EN_CB0740999.htm (accessed on 15 January 2020).

39. Zhang, S.; Zhou, Q.; Lu, X.; Song, Y.; Wang, X. Solubility and Diffusivity of 1-butyl-3-methylimidazolium 1,1,2,2-tetrafluoroethanesulfonate Mixtures. In Physicochemical Properties of Ionic Liquid Mixtures; Springer: Berlin, Germany, 2016.

40. Zhou, T.; Chen, L.; Ye, Y.; Chen, L.; Qi, Z.; Freund, H.; Sundmacher, K. An overview of mutual solubility of ionic liquids and water predicted by COSMO-RS. Ind. Eng. Chem. Res. 2012, 51, 6256-6264. [CrossRef]

41. Iolitec. Technical Data Sheet Trihexyltetradecylphosphonium Chloride; Iolitec: Heilbronn, Germany, 2011.

42. Iolitec. Technical Data Sheet Trihexyltetradecylphosphonium Bromide; Iolitec: Heilbronn, Germany, 2011.

43. Iolitec. Safety Data Sheet Tetraoctylphosphonium Bromide (CYPHOS IL-166); Iolitec: Heilbronn, Germany, 2015.

44. Åkerstedt, J.; Gorlov, M.; Kloo, L. Room-Temperature Synthesis of the Bi5[GaCl4]3 Salt From Three Different Classes of Ionic Liquids. J. Clust. Sci. 2013, 24, 157-164. [CrossRef]

45. Zhou, Y.; Roberson, A.J.; Hillhouse, J.H.; Baumann, D. Phosphonium and Imidazolium Salts and Methods of Their Preparation. U.S. Patent US7638636B2, 16 August 2002.

46. Iolitec. Technical Data Sheet Trihexyltetradecylphosphonium Bis(2,4,4-trimethylpentyl)phosphinate; Iolitec: Heilbronn, Germany, 2018.

47. Iolitec. Technical Data Sheet Trihexyl(tetradecyl)phosphonium Decanoate; Iolitec: Heilbronn, Germany, 2013.

48. Iolitec. Technical Data Sheet Trihexyltetradecylphosphonium Dicyanamide; Iolitec: Heilbronn, Germany, 2011.

49. Iolitec. Technical Data Sheet Tributylmethylphosphonium Methyl Sulfate (CYPHOS IL-108); Iolitec: Heilbronn, Germany, 2013.

50. Iolitec. Technical Data Sheet Trihexyltetradecylphosphonium Bis(trifluoromethylsulfonyl)imide; Iolitec: Heilbronn, Germany, 2011.

51. Iolitec. Technical Data Sheet Tributyltetradecylphosphonium Dodecylbenzenefulfonate; Iolitec: Heilbronn, Germany, 2011.

52. Iolitec. Technical Data Sheet 1-Butyl-1-Methylpyrrolidinium Hexafluorophosphate; Iolitec: Heilbronn, Germany, 2011.

53. Ventura, S.P.M.; Gonçalves, A.M.M.; Sintra, T.; Pereira, J.L.; Gonçalves, F.; Coutinho, J.A.P. Designing ionic liquids: The chemical structure role in the toxicity. Ecotoxicology 2013, 22, 1-12. [CrossRef]

54. Iolitec. Technical Data Sheet 1-Butyl-1-Methylpyrrolidinium Dicyanamide; Iolitec: Heilbronn, Germany, 2011.

55. Cumicheo, M.C.; Nobre, L.C.S.; Santos, A.F.; Lampreia, I.M.S.; Santos, M.S.C.S.; Santos, F.J.V.; Segura, H.; Nieto De Castro, C.A. Thermophysical Properties of 1-Butyl-1-methyl-pyrrolidinium Dicyanamide $+\mathrm{H}_{2} \mathrm{O}$ Mixtures. J. Chem. Eng. Data 2015, 60, 3766-3775. [CrossRef]

56. Iolitec. Technical Data Sheet 1-butyl-1-methylpyrrolidinium Trifluoromethanesulfonate; Iolitec: Heilbronn, Germany, 2012.

57. Fadeeva, T.A.; Husson, P.; Devine, J.A.; Costa Gomes, M.F.; Greenbaum, S.G.; Castner, E.W. Interactions between water and 1-butyl-1-methylpyrrolidinium ionic liquids. J. Chem. Phys. 2015, 143, 064503. [CrossRef]

58. Iolitect. Technical Data Sheet 1-Ethyl-1-Methylpyrrolidinium Bis(trifluoromethylsulfonyl)imide; Iolitec: Heilbronn, Germany, 2011.

59. Iolitec. Technical Data Sheet 1-Butyl-1-Methylpyrrolidinium Bis(trifluoromethylsulfonyl)imide; Iolitec: Heilbronn, Germany, 2011.

60. Ortega, J.; Vreekamp, R.; Marrero, E.; Penco, E. Thermodynamic properties of 1-butyl-3-methylpyridinium tetrafluoroborate and its mixtures with water and alkanols. J. Chem. Eng. Data 2007, 52, 2269-2276. [CrossRef]

61. Bandrés, I.; Giner, B.; Gascón, I.; Castro, M.; Lafuente, C. Physicochemical Characterization of n-Butyl-3-methylpyridinium Dicyanamide Ionic Liquid. J. Phys. Chem. B 2008. [CrossRef]

62. Kalčíková, G.; Zagorc-Končan, J.; Žnidaršič-Plazl, P.; Gotvajn, A.Ž. Assessment of environmental impact of pyridinium-based ionic liquid. Fresenius Environ. Bull. 2012, 21, 2320-2325. 
63. Benito, J.; García-Mardones, M.; Pérez-Gregorio, V.; Gascón, I.; Lafuente, C. Physicochemical study of n-ethylpyridinium bis(trifluoromethylsulfonyl) imide ionic liquid. J. Solut. Chem. 2014, 43, 696-710. [CrossRef]

64. Iolitec. Safety Data Sheet 1-Ethylpyridinium Bis(trifluoromethylsulfonyl)imde; Iolitec: Heilbronn, Germany, 2015.

65. Sigma-Aldrich. Safety Data Sheet Methyltrioctylammonium Chloride; Sigma-Aldrich: St. Louis, MO, USA, 2006.

66. Iolitec. Technical Data Sheet Choline Dihydrogenphosphate; Iolitec: Heilbronn, Germany, 2012.

67. Walker, A. Solvents. Patent WO2009034329A1, 19 March 2009.

68. Iolitec. Technical Data Sheet Methyltrioctylammonium Bis(trifluoromethylsulfonyl)imide; Iolitec: Heilbronn, Germany, 2012.

69. Iolitec. Safety Data Sheet IoLiLyte C1EG; Iolitec: Heilbronn, Germany, 2015.

70. Iolitec. Safety Data Sheet IoLiLyte T2EG; Iolitec: Heilbronn, Germany, 2010.

71. Iolitec. Safety Data Sheet IoLiLyte 221PG; Iolitec: Heilbronn, Germany, 2015.

72. Iolitec. Technical Data Sheet Choline Bis(trifluoromethylsulfonyl)imide; Iolitec: Heilbronn, Germany, 2016.

73. Nockemann, P.; Binnemans, K.; Thijs, B.; Parac-Vogt, T.N.; Merz, K.; Mudring, A.V.; Menon, P.C.; Rajesh, R.N.; Cordoyiannis, G.; Thoen, J.; et al. Temperature-driven mixing-demixing behavior of binary mixtures of the ionic liquid choline bis(trifluoromethylsulfonyl)imide and water. J. Phys. Chem. B 2009, 113, 1429-1437. [CrossRef]

74. Iolitec. Technical Data Sheet 1-Butyl-1-Methylpiperidinium Bis(trifluoromethylsulfonyl)imide; Iolitec: Heilbronn, Germany, 2012.

75. Russina, O.; Caminiti, R.; Triolo, A.; Rajamani, S.; Melai, B.; Bertoli, A.; Chiappe, C. Physico-chemical properties and nanoscale morphology in N-alkyl-N-methylmorpholinium dicyanamide room temperature ionic liquids. J. Mol. Liq. 2013, 187, 252-259. [CrossRef]

76. Iolitec. Technical Data Sheet Triethylsulfonium Bis(trifluoromethylsulfonyl)imide; Iolitec: Heilbronn, Germany, 2012.

77. Couling, D.J.; Bernot, R.J.; Docherty, K.M.; Dixon, J.N.K.; Maginn, E.J. Assessing the factors responsible for ionic liquid toxicity to aquatic organisms via quantitative structure-property relationship modeling. Green Chem. 2006, 8, 82-90. [CrossRef]

78. Luis, P.; Ortiz, I.; Aldaco, R.; Irabien, A. A novel group contribution method in the development of a QSAR for predicting the toxicity (Vibrio fischeri EC50) of ionic liquids. Ecotoxicol. Environ. Saf. 2007, 67, 423-429. [CrossRef]

79. Pretti, C.; Chiappe, C.; Baldetti, I.; Brunini, S.; Monni, G.; Intorre, L. Acute toxicity of ionic liquids for three freshwater organisms: Pseudokirchneriella subcapitata, Daphnia magna and Danio rerio. Ecotoxicol. Environ. Saf. 2009, 72, 1170-1176. [CrossRef]

80. Romero, A.; Santos, A.; Tojo, J.; Rodríguez, A. Toxicity and biodegradability of imidazolium ionic liquids. J. Hazard. Mater. 2008, 151, 268-273. [CrossRef]

81. Ranke, J.; Müller, A.; Bottin-Weber, U.; Stock, F.; Stolte, S.; Arning, J.; Störmann, R.; Jastorff, B. Lipophilicity parameters for ionic liquid cations and their correlation to in Vitro cytotoxicity. Ecotoxicol. Environ. Saf. 2007, 67, 430-438. [CrossRef]

82. Stepnowski, P.; Składanowski, A.C.; Ludwiczak, A.; Łaczyńska, E. Evaluating the cytotoxicity of ionic liquids using human cell line HeLa. Hum. Exp. Toxicol. 2004, 23, 513-517. [CrossRef] [PubMed]

83. Matzke, M.; Arning, J.; Ranke, J.; Jastorff, B.; Stolte, S. Design of Inherently Safer Ionic Liquids: Toxicology and Biodegradation. In Handbook of Green Chemistry; Wiley-VCH Verlag GmbH \& Co. KGaA: Weinheim, Germany, 2010; pp. 233-298.

84. Pernak, J.; Sobaszkiewicz, K.; Mirska, I. Anti-microbial activities of ionic liquids. Green Chem. 2003, 5, 52-56. [CrossRef]

85. Latała, A.; Stepnowski, P.; Nȩdzi, M.; Mrozik, W. Marine toxicity assessment of imidazolium ionic liquids: Acute effects on the Baltic algae Oocystis submarina and Cyclotella meneghiniana. Aquat. Toxicol. 2005, 73, 91-98. [CrossRef]

86. Hernández-Fernández, F.J.; Bayo, J.; Pérez de los Ríos, A.; Vicente, M.A.; Bernal, F.J.; Quesada-Medina, J. Discovering less toxic ionic liquids by using the Microtox ${ }^{\circledR}$ toxicity test. Ecotoxicol. Environ. Saf. 2015, 116, 29-33. [CrossRef] [PubMed]

87. Alvarez-Guerra, M.; Irabien, A. Design of ionic liquids: An ecotoxicity (Vibrio fischeri) discrimination approach. Green Chem. 2011, 13, 1507-1516. [CrossRef] 
88. Tether, A.L.; Laverty, G.; Puga, A.V.; Seddon, K.R.; Gilmore, B.F.; Kelly, S.A. High-throughput toxicity screening of novel azepanium and 3-methylpiperidinium ionic liquids. RSC Adv. 2020, 10, 22864-22870. [CrossRef]

89. Kebaili, H.; de los Ríos, A.P.; Salar-García, M.J.; Ortiz-Martíne, V.M.; Kamechec, M.; Hernández-Fernández, J.; Hernández-Fernández, F.J. Evaluating the toxicity of ionic liquids on Shewanella sp. for designing sustainable bioprocesses. Front. Mater. 2020, submitted.

90. Viboud, S.; Papaiconomou, N.; Cortesi, A.; Chatel, G.; Draye, M.; Fontvieille, D. Correlating the structure and composition of ionic liquids with their toxicity on Vibrio fischeri: A systematic study. J. Hazard. Mater. 2012, 215-216, 40-48. [CrossRef]

91. Lou, W.Y.; Zong, M.H.; Smith, T.J. Use of ionic liquids to improve whole-cell biocatalytic asymmetric reduction of acetyltrimethylsilane for efficient synthesis of enantiopure (S)-1-trimethylsilylethanol. Green Chem. 2006. [CrossRef]

92. Santos, A.G.; Ribeiro, B.D.; Alviano, D.S.; Coelho, M.A.Z. Toxicity of ionic liquids toward microorganisms interesting to the food industry. RSC Adv. 2014. [CrossRef]

93. Ranke, J.; Mölter, K.; Stock, F.; Bottin-Weber, U.; Poczobutt, J.; Hoffmann, J.; Ondruschka, B.; Filser, J.; Jastorff, B. Biological effects of imidazolium ionic liquids with varying chain lengths in acute Vibrio fischeri and WST-1 cell viability assays. Ecotoxicol. Environ. Saf. 2004, 58, 396-404. [CrossRef]

94. Swatloski, R.P.; Holbrey, J.D.; Rogers, R.D. Ionic liquids are not always green: Hydrolysis of 1-butyl-3methylimidazolium hexafluorophosphate. Green Chem. 2003, 5, 361-363. [CrossRef]

95. Becke-Goehring, M. Phosphorus and its Compounds. Angew. Chemie 1961, 73, 552. [CrossRef]

96. Huddleston, J.G.; Visser, A.E.; Reichert, W.M.; Willauer, H.D.; Broker, G.A.; Rogers, R.D. Characterization and comparison of hydrophilic and hydrophobic room temperature ionic liquids incorporating the imidazolium cation. Green Chem. 2001, 3, 156-164. [CrossRef]

97. Cornmell, R.J.; Winder, C.L.; Tiddy, G.J.T.; Goodacre, R.; Stephens, G. Accumulation of ionic liquids in Escherichia coli cells. Green Chem. 2008, 10, 836-884. [CrossRef]

98. Sena, D.W.; Kulacki, K.J.; Chaloner, D.T.; Lamberti, G.A. The role of the cell wall in the toxicity of ionic liquids to the alga Chlamydomonas reinhardtii. Green Chem. 2010, 12, 1066-1071. [CrossRef]

99. Latała, A.; Nędzi, M.; Stepnowski, P. Toxicity of imidazolium and pyridinium based ionic liquids towards algae. Bacillaria paxillifer (a microphytobenthic diatom) and Geitlerinema amphibium (a microphytobenthic blue green alga). Green Chem. 2009, 11, 1371-1376. [CrossRef]

100. Weuster-Botz, D. Process intensification of whole-cell biocatalysis with ionic liquids. Chem. Rec. 2007. [CrossRef]

101. Dickinson, Q.; Bottoms, S.; Hinchman, L.; McIlwain, S.; Li, S.; Myers, C.L.; Boone, C.; Coon, J.J.; Hebert, A.; Sato, T.K.; et al. Mechanism of imidazolium ionic liquids toxicity in Saccharomyces cerevisiae and rational engineering of a tolerant, xylose-fermenting strain. Microb. Cell Fact. 2016. [CrossRef] 